\title{
Mysticism meets Inception
}

\author{
Interreligious Dialogue emerging in Great Britain (World \\ Congress of Faiths / 1933-1950)
}

\section{Introduction: Theological Liberalism and the Founding of the World Congress of Faiths}

In the wider framework of the present publication, the chapter at hand deals with one of the earliest organizations of interreligious dialogue (IRD) in Europe. The World Congress of Faiths (WCF) was officially established in 1936 under the primary influence of Sir Francis Younghusband. The organization began its activities during a precarious period of time between two of the most destructive wars humanity has seen (World War I (1914-1918) and World War II (1939-1945)). The present study focuses on a period in the history of the IRD movement when interreligious dialogue (IRD) was emerging as an eclectic idea that created spaces for encounters among people who never before had the opportunity to engage each other on a deeper level socially in Europe.

Against this background, this chapter looks at two closely entwined elements. It aims to: first, learn more about Sir Francis Younghusband's motives that lead to the establishment of the WCF, as well as the specific role he played in that context; and secondly, relate Younghusband's activities back to the time between the two wars and analyze the influence of this particular context on the history of the WCF. In examining these two main points, this chapter proposes that on an individual level Younghusband's experience triggered the foundation of the WCF while on a social level, this was framed within the context of the Great Depression and the looming World War II that created the space for interreligious dialogue to emerge in the UK.

To better understand the developments that stood at the centre of WCF's foundation, as well as the very centre of Younghusband's personal motives, the analysis starts from two entwined theoretical concepts that have gained increasing significance in the field of IRD research.

The first concept focuses on the individual level. In this respect, Younghusband's work for the WCF is linked to what Mayra Rivera describes as the formation of the "ultimate openness", where one "remains open to mystery and unpre- 
dictable possibilities: to the ineffable, unnamable, and unutterable." As a result of this "openness" Younghusband became central in organizing the WCF and inspiring his peers to join him in developing the first interreligious association in Britain.

The second concept refers to the work of John R. Friday who connects the beginning of the IRD movement as the "rise of theological liberalism," a lens that focuses on the human experience with religion. ${ }^{2}$ More specifically, Friday examines James Fredericks' analysis of Friedrich Schleiermacher's writings on the human experience with the divine characterized as a personal experience combined with a "sheer immediacy," only later followed by critical thinking making it central to religion. Fredricks argues that religion, according to Schleiermacher, "is a matter of intuition, sense or feeling and should be considered a matter of doctrine only secondarily." 3

This adds a more general dimension to the discussion. ${ }^{4}$ This is a fitting frame from which to analyze Younghusband's experiences in relation to the establishment of IRD in the United Kingdom (UK). This liberalism is reflected in Younghusband's personal religious experience rebelling against his traditional Christian family by questioning Christian dogma and by participating in religiously diverse modes of worship. As a result, Youngbusband's personal experience is analyzed by examining archival material to determine how he moved towards becoming involved in the IRD movement and how his experience influenced the mission and vision of the WCF.

This chapter begins by describing the structure of the World Congress of Faiths and the key players involved in establishing the organization. By examining the WCF's early organizational structure and the socio-economic profiles of the people involved, this chapter aims to examine how the organization evolved from its inception. Using archive materials from the University of Southampton and Harvard University, this chapter pieces together experiences of the WCF members to show how they combined radical ideas of love and peace during a period of time plagued by war and economic depression. Even though WCF members dealt with frustrations mingled with a sense of despair at the end of World War II (WWII), facing the daunting process of rebuilding their communi-

1 Mayra Rivera, A Touch of Transcendence: A Postcolonial Theory of God (Louisville, Kentucky: Westminster John Knox Pres, 2007), 136.

2 John R. Friday, "Religious Experience, the Hermeneutics of Desire, and Interreligious Dialogue,” Theological Studies 74 (2013): 582.

3 Friday, "Religious Experience, the Hermeneutics of Desire," 583.

4 James L. Fredericks, “A Universal Religious Experience? Comparative Theology as an Alternative to a Theology of Religions,” Horizons 22 (1995): 67-87. 
ties, their resilience led to maintaining a movement that has influenced IRD concepts today. The importance of looking at this particular period of time is critical as it shows how the WCF has continued to survive since its official foundation in 1936, while other organizations have not.

While acknowledging the importance of the role that the WCF played in beginning the IRD movement in the UK, there are also lessons that emerge from the organization's experience. The visionary leadership of Younghusband led to a type of dependency on him, which took a toll on the unprepared WCF members after his death, reflecting one lesson for the IRD movement that is expanded upon in this chapter. A second lesson is that IRD was founded on the premise of Christian superiority. ${ }^{5}$ Lastly, an analysis of these issues reflects on how the IRD moved from being a fringe movement in its beginnings to transforming into a larger mainstream movement.

The formation of the WCF cannot properly be understood without having a closer look at its socio-cultural context.

\section{The WCF and the Socio-cultural Context of its Founding Members.}

The following sections provide a short overview of the WCF's general goals and objectives, as well as its historic context to better understand the processes that are later analyzed in more detail. They aim to underline to what extent Younghusband's individual convictions were linked to the context of his time and how these two aspects influenced the early history of WCF.

\subsection{Formation of WCF's Objectives and Goals}

Any analysis on the formation of the WCF needs to start with Younghusband. Younghusband was not looking to form a new religion or spiritual practice in the founding of the WCF - although his own personal experience with mysticism

5 The idea of Christian hegemony or agenda playing a role in the establishment of the early interreligious movement isn't something that just impacted the WCF, as Hedges notes in relation to the 1893 World Parliament of Religions "It should be noted, though, that an agenda of Christian supremacy and aspects of racial and cultural exclusion lay behind this event." Paul Hedges, Controversies in Interreligious Dialogue and Theology of Religions (London: SCM Press, 2010), 59. 
and engaging the divine heavily influenced the founding of the WCF. He once wrote:

The fully self-conscious human being knows himself to be not only a part of the Universal, but also a microcosm of it. This consciousness comes to its fullest realization in the mystical experience. He who experiences it is aware, as never before, that he is in very truth "a partaker of the divine nature."

This engagement with what he perceived as a mystical experience became a thread that emerged in the vision, objectives, and mission of the early WCF congresses. In reference to Younghusband's spirituality, Braybrooke interprets it as "the human fellowship that he [Younghusband] sought to promote was inextricably linked to communion with the divine. The Congress, therefore, was an attempt to give practical expression to the mystic's vision of unity."7 Younghusband's move towards universalism focused on elements of joy and love and influenced the concept of what fellowship means, as Younghusband states, "at its intensest and highest, fellowship seems to be a communion of spirit greater, deeper, higher, wider, more universal, more fundamental than any of these than even love." These examples portray Younghusband's engagement with mysticism, which he explores in the book Modern Mystic published in 1935 before the first WCF Congress was held in 1936. This article takes a deeper look into how Younghusband's mysticism influenced his involvement in the IRD movement leading to the inception of the WCF described below.

While Younghusband had been collaborating with people of diverse faiths via his travels in India, Tibet, Lhasa and other places in South Asia, he had not formally organized an official interfaith event until 1924 when he became Committee Chairman for the organization, A Society for Promoting the Study of Religions. This position became a catalyst for connecting him to the World's Fair in Chicago, the "First International Congress of the World Fellowship of Faiths," where he was a speaker. ${ }^{9}$ Through these networks and his growing popularity as a speaker on unity among religions, he was asked to host an interreligious congress in England. Younghusband left the World's Fair in Chicago "feeling that this was the long-looked-for opportunity of fulfilling his life's purposes

6 Francis Younghusband, Vital Religion (London: John Murray, 1940), 3-5, quoting 2 Peter 1:4. 7 Rev. Marcus Braybrooke is the current President of the WCF. Marcus Braybrooke, Faiths in Fellowship: The World Congress of Faiths (London: WCF-Publications), 7. Emphasis added.

8 Younghusband, Vital Religion, 93. Emphasis added.

9 George Seaver, Francis Younghusband (London: John Murray, 1952), 333. 
he accepted without hesitance. He had not sought it; it had been put into his hands."10

This eventually led to the establishment of the WCF. Younghusband strategically networked to pull in prominent leaders from various faith communities and leaders on religious thought, including his own to establish support for a congress in England. He realized the challenges that he would face in the formation of a larger organization when he received mixed reactions from the Anglican Church. Accordingly, to increase support, Younghusband used the connections he had with the media such as BBC to advertise the 1936 World Congress of Faiths held at the University College of London from 2 July to 18 July. ${ }^{11}$

With the help of many co-organizers, Younghusband developed a structure for the first congress, in the form of objectives and goals that were adopted within what came to be known as WCF as a result of this event. His desire was to create a fellowship of like-minded people based on mysticism, as he stated in a talk in Kent before the congress:

The ultimate aim of the Fellowship can only be to intensify our sense of kinship with the universe to the mystic degree - to the point when the individual feels as if he and the universe were madly in love with one another. ${ }^{12}$

Younghusband emphasized maintaining kinship through mysticism by using three main concepts of the Second Chicago World Parliament of Religions:

- $\quad$ To work for fellowship

- To welcome the necessary difference among members of any fellowship

- To unite the inspiration of all Faiths upon the solution of man's present problems. ${ }^{13}$

As a result, the WCF also published its vision and objectives founded on the kinship and mysticism Younghusband spoke of earlier, as quoted in a formal pamphlet for public distribution:

10 Seaver, Francis Younghusband, 333.

11 World Congress of Faiths, Program and Agenda of the first World Congress of Faiths (July $3^{\text {rd }}-18^{\text {th }}, 1936$ ), MS 222 A $826 / 3 / 98$, WCF Archives, University of Southampton. (The boxes are quoted according to the guidelines of the respective archives.)

12 N.A., Talk at Westerham / Kent, MSS EUR F 197/119, The Younghusband Collection, British Library, London, 11.

13 World Congress of Faiths, Program and Agenda of the first World Congress of Faiths, MSS EUR F 197/119, The Younghusband Collection, British Library, London, 3. 
Vision:

To promote a spirit of fellowship among mankind through religion and to awaken and develop a world loyalty while allowing full play for the diversity of men, nations and faiths. ${ }^{14}$

Objectives of the WCF:

The object of the World Congress of Faiths is to promote a spirit of fellowship among mankind through religion, however, interpreted in its wide and universal sense. A sense far transcending its particular expression in any one of the World's Faiths, and penetrating to that divine essence we believe to be common to them all. ${ }^{15}$

This pamphlet gives an interesting insight into how Younghusband was inspired by concepts of transcendence, immanence, and mysticism, and how these concepts were woven into the larger vision of the organization. WCF meeting Minutes and the notes from the 1936 Congress also reflect the attraction that the early WCF members had with exploring these three concepts, especially after being swayed by Younghusband's passion. Professor Marcault, a French Professor of Psychology and a participant of the 1936 Congress, stressed the importance of universality in encouraging religious communities to collaborate on fellowship. As he stated, "peace and fellowship can only be constructive if they are incarnated in some positive religious aim in whose realization all faiths can agree to cooperate, and whose universality maintains them united." 16 The following analysis and episodes will reflect how universalism combined with concepts of transcendence and mysticism as thought of by Younghusband led to the founding of the WCF.

From 1940 onwards, the published list of objectives for projects and work of the WCF included an international element in its mission. Younghusband and the WCF leadership believed in expanding the organization beyond England. ${ }^{17}$ They did this with a belief "to bring pressure to bear on governments and public opinion and to produce such a change in national policies as may bring peace to

14 World Congress of Faiths, Its Objects, Message and Work, MS 222 A 826 /3/98, WCF archives, University of Southampton.

15 World Congress of Faiths, Its Objects, Message and Work, MS 222 A 826 /3/98, WCF archives, University of Southampton, 3.

16 Allen Douglas Millard, ed., Faiths and Fellowship: Being the Proceedings of the World Congress of Faiths (London: J.M. Watkings, 1936), 309.

17 Braybrooke states: "WCF is not really a world body, but rather a British-based organisation, although readership of its journal is scattered across the world and WCF has close relations with several other international interfaith organisations". In an Interview conducted with him, interview Braybrooke, also reaffirmed that the organisation did not live up to becoming the "world body” that Younghusband had envisioned. See: Braybrooke, Widening Vision, 38. 
mankind through the living religions of the world." 18 To manifest this belief, they made a list of objectives to achieve for both events and meetings as shown in Annex 1 . The annexe reflects a communication strategy for attracting and attaining members and for spreading the WCF vision. Additionally, Annex 1 portrays the types of meetings that they aimed to host, on a small-scale, to be held on a weekly basis amongst members and large-scale meetings open to the public. As stated in Annex 1, a goal of the WCF was to provide a space where people could "learn what others believe, what they think about life today and how they pray, meditate and worship" based on experience and not just intellectual thought. ${ }^{19}$

To better understand the setup of the WCF, it is necessary to have a look at the socio-cultural background of its members.

\subsection{Socio-Cultural Background of the WCF Members and Co-Founders}

At this stage, the socio-cultural background of the WCF members can only be assessed indirectly. In the planning processes of the WCF 1936 Congress, the supporters and Younghusband met on a weekly basis. During these meetings, it was decided that anyone could become a member if they contributed $£ 1.00 .^{20}$ Lord Samuel, who became Chairman after the death of Younghusband in 1942, reflected on two principles for WCF membership during a public meeting of the WCF with 750 people in attendance:

\footnotetext{
This movement does not enter into any of those disputations, it merely declares that all religions worthy of the name have at least two common principles: one that they seek righteous conduct in the individual; the other that they inculcate good-will among human societies, each with its own particularities and so each has its own element of universalism. ${ }^{21}$
}

The overall body of the WCF as an organization had a hierarchical leadership structure headed by a supervising council, under which there were three committees: The Executive Committee, an Action Committee and a Finance Committee.

18 World Congress of Faiths: Its Objects, Message and Work, 4.

19 World Congress of Faiths: Its Objects, Message and Work, 4-5.

20 World Congress of Faiths, Minutes of the Executive Committee Meeting (1936), MS 222 A 826 2/1, WCF Archives, University of Southampton.

21 World Congress of Faiths, Annual Meeting Paper (June $4^{\text {th }}$, 1943), MS 222 A 826 2/1, WCF archives, University of Southampton. 
There was a National Chairman who presided over meetings, events and writing the chairman's quarterly letters, a Treasurer to keep track of finances and membership dues, and a Secretary to keep track of meeting and event notes, as well as, to deliver communication to members. The council members were elected through an electoral system. Additionally, elected officers had an option of taking a short sabbatical for a year and then opt to run for re-election. ${ }^{22}$

The WCF membership predominantly consisted of Caucasian Christians even though there were some members from various faiths and traditions. All members regardless of their backgrounds reflected similar socio-economic and educational backgrounds. It is difficult to argue that the membership reflected diversity, as members from diverse faith traditions such as Islam, Judaism, and Buddhism etc. were few in number and were considered to be representatives of their respective faith groups. This led to the same people being invited to speak at IRD events which occurred during this time. As a result, it can be argued this represented a lack of diversity, as these speakers became the 'go-to' ambassadors for their religions. It is hard to say if the Great Depression impacted the membership from drawing on more economically diverse membership, especially as Younghusband specifically targeted supporters who were government officials and intellectual elites in the fields of religious thought and philosophy. What is apparent, however, is that the privilege present in the earlier membership of the WCF might reflect the reason why the organization began to struggle financially when its wealthy supporters began to disappear.

The next section analyzes how Younghusband grew through various interreligious experiences to inspire his peers to create a space for the IRD movement in the UK that occurred alongside the rise of the theological liberalism. To accomplish this, this section examines manifold data sources from the WCF archives and aims to underline how the research agenda sketched in the introduction can be translated into a concrete research agenda.

Using Brundage's definition of primary documents, both manuscripts, which are original unpublished documents such as meeting Minutes, and published documents, such as Younghusband's books on his travel experiences, were used for this research. When referring to archival sources, I am referring to the University of Maryland's definition: “Archives are usually unpublished, primary source material that document the activities of an individual or organization." ${ }^{23}$

22 World Congress of Faiths, Minutes detailing the development of leadership (from 1936 1949), MS 222 A 826 1/1, WCF Archives, University of Southampton.

23 University of Maryland, Definition: Archives: http://www.lib.umd.edu/special/research/de fine/archives.html (accessed: 24.5.2020). 
According to Brundage, secondary sources rely mostly on primary sources to make a case for their argument, such as websites and books on encompassing broad topics. $^{24}$

More concretely, the materials used for this empirical research incorporate a combination of primary and secondary sources compiled during May 2014 at the University of Southampton and the London-based British Library in the United Kingdom. Archival research was also conducted at the Harvard Libraries in Cambridge, Massachusetts in the USA during September 2014.

The primary documents are from the World Congress of Faith Archives in the University of Southampton archives. They included Reverend M. C. R. Braybrooke's MS Papers, which were contained in sixty-three boxes.

Additionally, I used the World Congress of Faiths' MS 222 Archives consisting of thirty-five boxes. I chose to focus my analysis using these archives as they portrayed firsthand accounts of the formation of the WCF and its struggles from 1920 - 1950. I also interviewed Reverend Marcus Braybrooke the current President of the WCF, who provided background for my argument based on his own published research. As a result, I used a combination of research tools from manuscripts and published sources, as shown in Annex 2, in addition to interviews.

Furthermore, a combination of secondary sources published on the World Congress of Faiths, including books, websites and articles from the aforementioned libraries were consulted for this research, as well as research conducted online. A critical reading of these sources helped support the thesis of this chapter portraying how Younghusband's experiences with trauma, mysticism, and empathy triggered the establishment of the WCF. Lastly, additional sources were used to frame the implications for the future of interreligious dialogue in the conclusion.

On this basis, it is possible to compare three periods in the formative history of the WCF, which help us understand the dynamics of this initial phase by focusing on the role of Younghusband.

\section{Sir Francis Younghusband and Mysticism}

Sir Francis Younghusband struggled throughout his life with the feeling of there being more than the everyday stagnant and conventional practice of religion. His

24 Anthony Brundage, Going to the Sources: A Guide Historical Research and Writing (Wheeling, Illinois: Harlan Davidson Inc, 2002), 19-30. 
various experiences growing up in India with his family on a Christian mission and experiences back in England show his desire to move towards a higher understanding of the divine. In a letter Younghusband sent to Mary Clark of Tunbridge Wells in May 1938, Younghusband claims to have engaged in mysticism, "I hope I am right in thinking that you have enjoyed a direct experience of God - an experience of communion with the Central Spirit of Things and have known what intensity of joy and exaltation of spirit that mystical experience brings." 25 Younghusband describes another mystical experience he had at a Welsh Revival meeting in 1905 in his book, Modern Mystic. It was a mystical experience within a Christian context that left him feeling "as if I were in love with every man and woman in the world." ${ }^{26}$ These significant experiences reflect in some part the motivation for why Younghusband became a leader in the early IRD movement.

Several experiences defined Younghusband's spiritual journey growing up and as an adult. The most prominent was his involvement in the mission to Tibet on behalf of the British Government in 1903. Another was a car accident later on in life, which affected his health thereafter. As he stated,

As I grew up into manhood, less and less could I rest satisfied in the conception of a god who must be approached and placated by means of ritual, and more and more did theology and ecclesiasticism obtrude themes as barriers- rather than offer themselves as bridges- to the understanding of an all-loving universal power. ${ }^{27}$

Younghusband came to "think of Jesus Christ as a real man, with all the frailties of men, who became great because of indomitable courage." 28 These experiences led him on the path of seeking spirituality in the form of mysticism focusing on universalism. Hence, it is no surprise that during the establishment of the WCF Younghusband merged elements of mysticism into the objectives of the organization.

Examining certain life-changing events in Younghusband's life gives us important insight into the formation of his thinking, leading to a sense of openness and visionary leadership that was essential in getting the WCF off the ground and also in giving it momentum to continue regardless of ideological hurdles.

25 Braybrooke, Widening Vision, 21.

26 Francis Younghusband, Modern Mystic (New York: E.P. Dutton and Company Inc, 1935), $214-$ 246. See also: George Harrison, Unpublished Manuscript: Younghusband Anthology of Divine Fellowship, 212 A814 56/2, WCF Archives, University of Southampton.

27 Seaver, Francis Younghusband, 14.

28 Braybrooke, Widening Vision, 25. 
The first of three experiences that led Younghusband's movement towards "ultimate openness" was a horse accident that he had in 1894 as a youth. Writing in his diary before this accident occurred, Younghusband wrote, "I think I have had from time to time the feeling that I was born to recognize the divine spark within me [...] I shall through my life be carrying out God's Divine message to mankind."29

After being thrown from his horse he lay unconscious on the ground for fourteen hours. During his recovery period, he began to explore Leo Tolstoy, and wrote in his diary,

I now see the truth of Tolstoy's argument that Government, capital and private property are evils. We ought to devote ourselves to carrying out Christ's saying, to love one another (not engage in wars and preparation for wars and not resist evil with evil) [...] And this is what I mean to do. To set the example first of all by giving up government service and all my private property, except what is absolutely necessary for supporting life. ${ }^{30}$

Younghusband was “deeply impressed” by Leo Tolstoy's, The Kingdom of God is Within You. It played a role influencing his early spiritual growth. ${ }^{31}$ This immediate development around the time of the accident makes it plausible that the experience with his accident, his long recovery process and in the meantime discovery of Tolstoy's philosophy led him to leave government service. However, Younghusband eventually rejoined government service after marriage, leading him back to India. His fascination with Tolstoy suggests the beginning of his experience with transcendence where he begins to have desires to engage the other or the divine through human experiences with religion beyond Christianity.

After marrying and having a daughter, he became involved in politics again at which point he was invited to move to India to take up a government post. It was in India, in 1904, that Younghusband had a second critical experience that shaped his transformation toward IRD. He became involved in leading a mission to Tibet to secure a treaty for economic concessions and to prevent a Russian alliance. What seemed to Younghusband as a simple mission turned into something more controversial when the British advance, he was a part of came upon poorly armed Tibetan soldiers at the city of Chumi Shengo. A struggle over disarming the Tibetans, led to one shot ringing out from the Tibetan side resulting in a massacre of hundreds of Tibetans dubbed by Younghusband as

29 A quote from Younghusband's dairy as quoted in: Patrick French, Younghusband: The Last Great Imperial Adventurer (London: HarperCollins, 1994), 109.

30 Younghusband, Diaries, quoted after: French, Younghusband: The Last Great Imperial Adventurer, 109.

31 Braybrooke, Widening Vision, 26. 
"the Guru Disaster."32 While Seaver's account of Younghusband's mission in Tibet reflects that 600-700 men were killed on the Tibetan side, other historians argue that almost 2,500 Tibetans were killed. ${ }^{33}$ The outcome of the mission led to some of Younghusband's British superiors denouncing his actions and others applauding the final outcome. In the end, his behaviour met British interests since a final treaty was signed in Lhasa. This was a controversial event that became and remained a point of struggle spiritually for Younghusband, to the point of regret. As Frank Smythe wrote in Younghusband's obituary for a newspaper, "I am sure that Sir Francis would like it mentioned here that is was a source of grief to him all through his life that he was forced in the first place to meet violence with violence." 34

After the treaty was signed, Younghusband stood on the side of the mountain peering down at the ancient city of Lhasa and had an experience, which he described as mystical. He later attributed his inspiration for the creation of the World Congress of Faiths to this experience. He described it as a feeling of "elation grew to exultation, and exultation to an exaltation which thrilled through me with overpowering intensity [...] Never again could I think evil. Never again could I bear enmity." 35 He continued on to state that it was "too rare" and in it "God is made real to us." 36 In this statement he related his realization, at the moment of his mystical experience, of the notions of universalism, the idea that we are all interdependent of each other in this universe. Also coming to the understanding of the sacredness of life, he stated:

The fully self-conscious human being knows himself to be not only a part of the Universal, but also a microcosm of it. This consciousness comes to its fullest realization in the mystical experience. He who experiences it is aware, as never before, that he is in very truth "a partaker of the divine nature." 37

Younghusband's experience portrays the reality of a spiritual struggle that people face in or after times of crisis, showing how mysticism or religious experiences can play a role in healing. While this event in Tibet was a dark part of Younghusband's past that haunted him, it led him afterwards to unexplored parts of

32 Seaver, Francis Younghusband, 227.

33 Charles Allen, “The Myth of Chumik Shenko," History Today 54 (2004): 17.

34 Frank Smythe, News Clipping: Lt.-Col. Sir Francis Younghusband (1942), MS 222 A 826 1/1, WCF archives, University of Southampton.

35 Younghusband, Vital Religion, 3-5.

36 Younghusband, Vital Religion, 3-5.

37 Younghusband, Vital Religion, 3-5. 
South Asia to engage in spiritual encounters with Buddhism and Islam in places such as Kashmir. In India, Younghusband's basic religious convictions developed in "two main ways": "in greater experience of the mystery of the universe and in broadening sympathy with, and understanding of, people of other faiths." ${ }^{38} \mathrm{He}$ took this understanding back to the UK when he began engaging in the burgeoning IRD movement.

Back in London, some politicians repudiated Younghusband's military mission as stepping out of bounds from his station. Others such as Lord Curzon, greatly commended him for getting a treaty signed. In his book, George Seaver shares a rumour of King George saying to Younghusband: "I am sorry that you have had this difference with the Government. All Governments have their little ways, you know. But, don't you bother your head. I approve of all you did." 39 He was eventually knighted by the King and was exonerated as acting in accordance with British interests in his mission to Tibet. Regardless, Younghusband felt moved by his spiritual epiphany, resulting in his departure from government service for good.

After his mission to Tibet, Younghusband decided to explore South Asia further, while mentally processing the events that occurred during his political career. During this time, he met people of different faiths and engaged with their rituals and worship ceremonies, which he spoke about in a BBC Broadcast announcing the first congress of the WCF:

[...] I have come into most intimate contact with adherent of all the worlds' religions, Hindus, Muslims, Buddhists, and Confucians. I have been dependent upon them for my life. The have been dependent upon me for theirs [...]. It has forced me down to the essentials of my own Christianity and made me see a beauty there I had not till then known. ${ }^{40}$

In 1911, it is possible to identify a third decisive event in Younghusband's biography. Again, he experienced an accident, but this time he was hit by a car in Belgium that severely injured him. He described later on the experience of laying in what he thought was his death bed, "the Belgian doctor arrived and informed the nurse that three days was the utmost that the patient could now live." ${ }^{\circ 1} \mathrm{How}$ ever, Younghusband survived beyond the three days predicted by the doctor and was eventually transported back to London with the help of his wife where he

38 Braybrooke, Widening Vision, 25.

39 Seaver, Francis Younghusband, 257.

40 Francis Younghusband, BBC Broadcast Script (June 21 1936), MS 222 A 826 3/98, WCF archives, University of Southampton, 1-2.

41 Seaver, Francis Younghusband, 281. 
was able to get the help of British doctors, whom he preferred. In personal accounts of this accident, he expressed his suffering and being in great pain without pain-alleviating medication. He also contracted pneumonia three times during the recovery process. His writings reflect his astonishment of human goodwill and the sympathy he received from strangers and friends alike during the excruciating healing process:

The bare souls were exposed; and of warm human sympathy I had more than I had ever dreamed possible should be given. To an intense degree I felt the oneness of all humanity. As I lay at death's door I was extraordinarily susceptible to every touch and shade of human feeling. In some unknown way, I seemed to touch heart to heart with every human being. ${ }^{42}$

Through this experience, he discovered the ability of people to empathize and feel compassionate towards those in need, something that he reflected upon at the first WCF congress. As a result, he entwined this sense of interconnectedness and empathy he felt, into the mission of the WCF and used it to attract members to the IRD movement. He also expressed this in a book he wrote during his recovery process, entitled Within. It describes his first written engagement with his personal experiences with eclectic religions and his move to universalism. In a follow-up book, the Light of Experience, he acknowledges that Within may have been too radical for its time based on criticism he received from Christian relatives:

I can see now that the view of Christianity, which I had taken, as a young man. And it was a struggle to reach a truer view. I stated my disbeliefs with perfect frankness, but perhaps too much of the freedom of expression I had been accustomed to see used in these Aristotelian Society debates. ${ }^{43}$

His exploration of how the divine exists inside humans emerged in Within. He elaborated that when someone is confronted with the experience of the "wholly good [...] then we may fitly trust it as our God, in place of the discarded Deity of our childhood." 44 While fifteen years later, in the Light of Experience, he acknowledged, "I can see that I laid too much stress on immanence and too little on transcendence," meaning that God exists above, as well as inside of us. ${ }^{45}$ This

42 Seaver, Francis Younghusband, 283.

43 Francis Younghusband, The Light of Experience (Boston and New York: Houghton Mifflin Company, 1927), 242.

44 Younghusband, The Light of Experience, 242.

45 Younghusband, The Light of Experience, 242. 
connects to the experience that Rivera, a contemporary theologian, points towards in her discourse on experiencing transcendence with an "ultimate openness," as a necessary tool to develop for religious scholars. She goes on to use Irigaray to emphasize that the space of difference in inter-human encounters should be "envisioned as that element that nurtures each one of us" instead of as a void or emptiness. ${ }^{46}$

Part of Younghusband's conclusion in Vital Religion was that joy and love were the foundation of all religions. ${ }^{47}$ In Modern Mystic, a narrative of his thoughts on mysticism, Younghusband clarifies how he perceived mysticism based on concepts of joy and love reflecting "the Universal spirit." 48 He goes on to argue the practicality of the mystical experience, "and it is because the mystical state refreshes, reinforces and refines the spirit in a man that it is of such value in practical life. As practical men, we have to cultivate the spirit and seek out whatever will strengthen it within us." ${ }^{49}$ In the conclusion of Modern Mystic he argued that trainings for this type of practical experience were "lacking" and advocated for universities and schools to facilitate the ability for students to meditate or have some form of space to experience mysticism. ${ }^{50}$ Needless to say, this suggestion was, for its time, provocative, based on examples of not just his experiences with the Welsh Revival, but also based on his observances of Hindu, Muslim, Catholic, and Protestant mystics. Published in 1935, Modern Mystic reflects the mindset of Younghusband as he began laying the foundation for the formation of the 1936 Congress and what would become the vision of WCF. ${ }^{51}$

46 Mayra Rivera, A Touch of Transcendence (Louisville, Kentucky: Westminster John Knox Pres, 2007), 136. Younghusband, wasn't the only scholar (I may even say scholar of religion) who was moved by the idea of transcendence in this period of time. It was already suggested that Rudolf Otto also was exploring mysticism and these concepts of the "wholly other." This feeling or human experience for him was so overpowering that it led him to "transition into mysticism", traces of a type of spiritual process he argues is present in all religions. These experiences with mysticism and transformation were the powerful motivating factor for Younghusband to creating the WCF so that he could help others have the same mystical experience. As a result, threads of mysticism emerge in the vision and objective of the WCF. See: Younghusband, The Light of Experience, 37.

47 Younghusband, Vital Religion, 5.

48 Younghusband, Modern Mystic, 292.

49 Younghusband, Modern Mystic, 284.

50 Younghusband, Modern Mystic, 287-288.

51 Additionally, Braybrooke argues that Younghusband's mysticism influenced, "his conception of a fellowship of faiths that sprang from a mystical sense of the unity of all people. The 'brotherhood of man' was for Sir Francis, not a religious slogan, but a truth realized in religious experience”. As a result, according to Braybrooke, Younghusband's larger intention in forming 


\section{The 1936 Congress}

The root of the idea of hosting the first interreligious dialogue in the form of a Congress in Great Britain was inspired at the second World Fair held in Chicago in 1933. There, two people - Younghusband describes them as "an Indian and an American" - encouraged him to organize a congress headed by a British National Council in London..$^{52}$ Kedaranth Das Gupta, founder of the organization Union of East and West and Charles F. Weller, founder of the League of Neighbours both merged their two organizations to create the Fellowship of Faiths in the USA. They were the main organizers of the 1933 World Fair. ${ }^{53}$

As shown in the formation of the 1936 Congress, Younghusband's ideas on mysticism influenced the larger aim, which was to "develop both the meeting of people with each other and their communion with the Divine so that the unity of mankind might become more obvious and complete." 54

At a preliminary decision-making meeting in November of 1934, Younghusband held a meeting of the All Peoples Association in Piccadilly where he invited notable leaders to take part in organizing the first congress. One of the ultimate results of the 1936 Congress was the founding of the World Congress of Faiths immediately after the proceedings ended. At this point, members were voted into various officer positions for the organization. The following people were put in leadership positions to organize the 1936 congress:

1. Mr. Arthur Jackman - Organizing Secretary

2. Miss. Mabel Sharples - Honorary Secretary

3. Mr. Frank Brown - Chairman of the Publicity Committee

4. Miss Beatrix Holmes (als. Beatrix Potter) - Information Secretary for the Publication Committee and also a member of the Executive Committee

5. Mr. F.P. Richter - Chairman of the Publications Committee

6. Mr. A. Douglas Millard - Editor

All of these people were also members of the larger Executive Committee, which was chaired by Younghusband and overseen by the International President, H.H.

the WCF was to "help members of all faiths become aware of the universal experience which had been his." through the use of interreligious dialogue. See: Braybrooke, Faiths in Fellowship, 6. 52 Francis Younghusband, Proposal for an International Congress of a World Fellowship of Faiths (June 1936), MS 222 A 826 2/2, WCF Archives, University of Southampton, 4.

53 Braybrooke, Faiths in Fellowship, 13-14.

54 Younghusband, Vital Religion, 97-98. 
Maharaja Gaekwar of Baroda. ${ }^{55}$ After its formation in 1935, Younghusband immediately took a lead in creating a proposal that would be used to "give members of Council and others interested a short account of the inception of the idea of a Fellowship of Faiths and some conception of the character, scope and aims of the proposed Congress," which was ultimately sold as a sixpenny pamphlet in July, 1936. An additional goal of the pamphlet was to assure people that the mission was not to create a new "synthetic religion," a reassurance that members of the WCF had to make throughout the initial stages of the establishment. This reflects one of the challenges that the organizers faced in terms of backlash from certain religious leaders in the establishment of the congress, which is discussed further on.

The program of the Congress outlined how it could be an answer to fight eight "evident evils", defined through the papers presented by speakers that were available to members before the Congress. Those eight evils were:

1. Fear

2. Hatred

3. Nationalism in excess or defect

4. Racial animosity

5. Class Prejudice

6. Poverty

7. Ignorance

8. Religious Differentiation ${ }^{56}$

The congress was held from 3-18 July 1936 at the University College of London. The theme was World Fellowship through Religion. As put down in the conference documents, the participants had a mix of private meetings for members and public meetings open to everyone, including devotional meetings and services led by members of all faiths represented at the meeting. This congress was the "first time in an inter-religious gathering, discussion was allowed and was carried on in good humour" a notable accomplishment of this IRD event. ${ }^{57}$ Furthermore, they had a Hindu-led yoga and meditation class, which indicated the open-minded thinking that the congress required. Members had to adjust to if they were not already in that mindset. The congress was two weeks long with 20 speakers from diverse faith backgrounds including Muslims, Jewish, Christian, Hindus, Baha'i, Buddhist, Confucian and people who claimed to be independent thinkers. In ad-

55 World Congress of Faiths, Program and Agenda of the first World Congress of Faiths (July $\left.3^{\text {rd }}-18^{\text {th }}, 1936\right)$, MS 222 A $826 / 3 / 98$, WCF Archives, University of Southampton, 3.

56 Program and Agenda of the First World Congress of Faiths, 4.

57 Braybrooke, Faiths in Fellowship, 10. 
dition to this, conference archives MS 222 A 826 2/2 reflect that there were at least 45 people involved in the organization of the congress up to the time it took place with additional people involved as volunteers.

The "Who's Who at the Congress" section listed a total of 50 prominent people including people who Younghusband had met at the 1924 Religions of the Empire Conference held in London and the 1933 World Fair in Chicago. ${ }^{58}$ While there is no record of the total attendance of the Congress, at least 100 people were in attendance some of whom were already involved in the burgeoning IRD movement. However, based on the congresses that followed the 1936 congress, archives reflect attendance numbers of up to 400 people; thus, it is likely that the first congress had a similar turnout especially given the prominent leaders involved, such as the Aga Khan H.H, the Rt. Hon. Aga Sultan Sir Mahomed Shah and Baroda, and H.H. The Maharaja Gaekwar. ${ }^{59}$ The first speaker to open the congress was Yusuf Ali who was the Principal of the Islamic College in Lahore and today is known to have translated one of the more widely used interpretations of the Quran. ${ }^{60}$ Another notable speaker was Sir Sarvepalli Radhakrishnan, who spoke about the History of India and later went to become the President of India. ${ }^{61}$ The fact that there were such notable leaders and monarchs involved in the 1936 Congress was part of the reason that King George of England sent a letter of welcome for Sir Francis Younghusband to read at the opening of the congress. However, the glaring absence of the King and high representatives of the Church of England was noticed. This point brings us to the challenge the 1936 Congress faced.

To better understand Younghusband's personal impact on the conference, it is helpful to approach it from the point of view of the critics that were opposed to Younghusband's use, namely by expressing the fear that interreligious dialogue would lead to conversion. ${ }^{62}$ For instance, WCF recorded that the Anglican Church refused to participate in the 1936 Congress as they "were in the business of conversion not conversation." Many other clergies from various faiths also did not participate. ${ }^{63}$ Instead, mostly religious scholars attended the 1936 Congress. As mentioned earlier, Younghusband attempted to dissuade the notion that the

58 Braybrooke, Faiths in Fellowship, 3-8.

59 Braybrooke, Faiths in Fellowship, 11-15.

60 Braybrooke, Widening Vision, 43.

61 Braybrooke, Widening Vision, 45.

62 Proposal, International Congress of World Fellowship of Faiths by Sir Francis Younghusband, $6-7$.

63 Marcus Braybrooke, “The Spiritual Basis of Interfaith Work,” Dialogue \& Alliance 19 (2005/ 2006): $23-27$. 
WCF would create a "synthetic religion" or attempt to convert members, as seen in the proposal he wrote to establish financial support for the 1936 Congress. ${ }^{64}$ At one point in the proposal, Younghusband specifically defines what he considers to be the fellowship of faith and particularly clarifies what he means by 'faith', differentiating it from what is perceived to be religion. Instead, he argues that the WCF would strengthen one's religious belief through a dialogue on commonalities with members of other faith, underlining the main component of the IRD movement today. ${ }^{65}$

As a result, Younghusband and the organizers of the 1936 Congress published a pamphlet for the public and the BBC broadcast amongst other marketing strategies to prevent this assumption largely being espoused by the Anglican Church. When Sir Francis Younghusband invited King George to the 1936 Congress the King sought advice from Archbishop of the Church of England who warned him against becoming involved. The two main concerns of the Anglican Church were first, that by being involved in the 1936 Congress the King and any Anglican Bishop would be admitting that there are many paths to God and that all religions are on an equal footing. This admittance of even limited validity of other religions would threaten the hegemony of the Anglican Church and also the British Empire. Secondly, another concern was that engaging various faiths and independent thinkers would introduce alternative thinking about religion that would be too radical for the Anglican Church to endorse.

The underlying assumption in this argument by the Anglican Church was that this would set the ground for conversion from the Church, a fear of the IRD movement that still persists today in some circles. This is reflected in the forward written by Younghusband in Faiths and Fellowship published after the congress, where he again attempts to prevent this misunderstanding. He insists that the 1936 Congress and the larger WCF founded through it, did not intend to compare religions, but rather to create a space to listen to each other's religious experiences, resulting in learning how people can come closer to God and to each other. ${ }^{66}$ Braybrooke, an Anglican priest himself, responded to a question on this episode saying that the Anglican Church was not theologically prepared to consider the benefits of being involved in interreligious engagement when the IRD movement began. ${ }^{67}$

64 Braybrooke, "The Spiritual Basis of Interfaith Work," 6-7.

65 Braybrooke, "The Spiritual Basis of Interfaith Work," 6-7.

66 Millard, Faiths and Fellowship, 9.

67 Reverend Marcus Braybrooke (President of the WCF), interviewed by Sana Saeed, May $4^{\text {th }}$, 2014. 
The Anglican Church was not the only faith community grappling with how to engage 'the other' theologically and in practice. A speaker at the 1936 WCF, Reverend P.T.R. Kirk also held a similar position. A representative of the Ahmadiyya Muslim Community at the 1936 WCF, Mr. Moulvri, also similarly felt that Islam should be accepted as a primary truth. Both speakers portray contradictions to the eight evils that Younghusband put forth to fight "religious differentiation" or religious superiority. Some messages contradicted the larger aim of the Congress to not make comparisons of religious beliefs by highlighting similarities or differences, such as Ranjee G. Shani stating, "Jesus and Buddha, Shakespeare and Ramakrishna [...] are in essence 'members one of another,", hence dismissing differences as trivial. ${ }^{68}$

These sentiments portrayed the nuances that played a role in how speakers at the Congress expressed themselves in addressing the eight evils. It also shows the fallacy of interfaith speakers being thought of as representatives of their faith and making controversial claims, such as all people should convert to their faith since their religion is superior. As shown by other Christian and Muslim participants in the Congress discussions, they did not fully agree with conversion as an answer to world problems being addressed. Professor Haldane stated in his paper:

Many Christians entertain the ideal of converting non-Christian people to Christianity. I think that a much higher ideal is to understand and enter into sympathy with the religions which exist in other countries and use the understanding and sympathy as a basis for higher religion. ${ }^{69}$

In his paper, Professor Haldane touches upon the same elements of empathy in engaging 'the other' as Younghusband discovered through his experiences with mysticism and spirituality. Sympathizing, in general, means relating to a person because one has had a similar experience, whereas empathizing means putting yourself in someone else's shoes by imagining their experience with compassion. Hence, the power of the imagination in connection to experiencing the divine comes into play here, where a person engaging in interreligious dialogue can both sympathize and empathize with the other's religious experience.

The above-described criticism directly addresses Younghusband's vision for the WCF connecting kinship to mysticism in a critical way. At the same time, it is interesting to see that while the critics grappled with ideas of their religious superiority or inclusiveness, they were also willing to engage in interreligious dia-

68 Millard, Faiths and Fellowship, 224.

69 Millard, Faiths and Fellowship, 131. 
logue as a way to prevent human disasters on the scale of a World War. In 1936, "the position of the Congress ruled out the view that any one religion has a monopoly on truth. It assumed that, despite differences, the world religions have an affinity, and share a recognition of spiritual reality and of ethical values."70 The congress in this respect encouraged the perspective that religious differences are vital and should be respected. Instead of focusing on differences as a dividing point, the 1936 Congress and following congresses focused on "the discovery of areas of ethical agreement and perhaps with taking common action on certain moral issues." ${ }^{\prime 11}$ In that sense, the group of eight evils listed earlier were seen by members as common moral issues that each religious group at the 1936 Congress could take action on, through the use of interreligious dialogue. For example, the third evil from the list, combating "nationalism in excess or defect" emerged from the rational nationalist rhetoric that had played a role in World War I, hence raising the importance of establishing harmony through IRD. However, unknown to the WCF members at this point in time, nationalism was on the rise again in Europe, particularly in Germany.

This directly leads to the third phase of this analysis: WCF's dependency on Younghusband, as well as its potential, to continue its activities.

\section{Challenges during WWII and after Younghusband's Death}

This period touches upon the decline in the momentum of the WCF during World War II and after the death of Sir Younghusband. As Braybrooke states, "the death of Sir Francis was a heavy blow to the Congress because it depended so much on his inspiration and effort and because no plans had been prepared for this possibility. Many too had taken part out of personal regard for Sir Francis."72 His death among other critical events became challenges for the survival of the WCF that reflect on how it went from being an organization involved in what some considered a fringe movement to what IRD is considered today, a respected mainstream movement.

As stated earlier, the WCF was officially established after the first 1936 Congress. The four congresses that followed, were successful, including one congress in Paris before the outbreak of World War II and a smaller intimate congress in

70 Braybrooke, Faiths in Fellowship, 11.

71 Braybrooke, Faiths in Fellowship, 11.

72 Braybrooke, Faiths in Fellowship, 14. 
Birmingham, England during the war in 1942. As reflected in the introduction, regular meetings of the WCF were held during World War II, and there are a series of letters highlighting the air raids while the WCF was open for business hours. In December 1940, Younghusband sent a letter updating members about the WCF and introducing a new member, Rev. Rabbi Salzberger, an asylum seeker, who moved to England from Frankfurt, Germany. During a WCF meeting, Rev. Rabbi Salzberger described what a traditional Jewish home was like for the non-Jewish WCF members. Younghusband described the aim of the meeting "was to make religion not a compartment of life, like science or art, but a constituent pervasive element in the whole life. For as long as our life is not collected together by one bent, we are at harmony with ourselves." ${ }^{\prime 3}$

Nevertheless, WWII also resulted in the financial decline of the WCF. The WCF archives and sources reflect that the outbreak of war drastically restricted the WCF operations including communications among members and made international congresses impossible. ${ }^{74}$ Despite the challenges, WCF continued to operate and elect new officers who were able to attend meetings. Baroness of Ravensdale - a supporter of the WCF since the founding of the organization and who became the Treasurer of the WCF in $1945^{75}$ - gave a moving speech at a meeting on Tuesday, 27 November 1945 in London:

We are all closer to the gutter and further from the stars than we were in 1939: our sensibilities have become blunted, our values reduced, we have slipped down the cliffs of civilization without being aware of that fact" indicating the toll the war had taken on peoples sense of hope that can also be linked to the overall decline of membership of the WCF. ${ }^{76}$

While the Baroness of Ravensdale gave fiery speeches on why interreligious engagement should be supported regardless of war and especially after war, the larger momentum began to decline. The archives reflect that they maintained an interfaith body of members during WWII including a director of an Islamic Cultural Center in London, two Rabbis, a Swami and many leaders of the Christian community who were in regular attendance and were elected to the executive committee. They held daily meetings where members took turns speaking. Nevertheless, the organization continued to financially decline after the war, be-

73 World Congress of Faiths Chairman's Letter, by Sir Francis Younghusband, Dec 1940.

74 Braybrooke, Faiths in Fellowship, 13.

75 World Congress of Faiths, Meeting Minutes (1945), MS 222 A 826 2/1, WCF Archives, University of Southampton.

76 World Congress of Faiths, Meeting Minutes (Nov 27 $7^{\text {th }}$, 1945), MS 222 A 826 2/1, WCF Archives, University of Southampton, 1-3. 
cause of the fact that the wealthier and prominent supporters were not as engaged as they were in the first two years. This can be linked to two entwined developments.

First, throughout the war, Younghusband kept up the momentum and inspiration to engage members. So, when he fell ill after the in 1942 Birmingham Congress the organization and officers of the WCF were ill-prepared to carry on the organization. The private Minutes of the meetings of the officers and speeches given at his memorial service reflect the sorrow of losing a visionary leader such as Younghusband, but also how dependent the members and officers had been on him as a source for inspiration. Beatrix Holmes, a member of the 1936 Congress organizing Executive Committee and longstanding WCF member paid tribute to his memory in George Seaver's book, Francis Younghusband: Explorer and Mystic. She explained how Younghusband "radiated happiness" 77 that was "infectious"78 even during wartime. According to Beatrix Holmes, "it was a delight to witness" joy that only mystics know, which springs from the fact that you love what is separate from yourself, and that love unites you."

Another WCF member, Rom Landau, who was originally from Poland and eventually became a British Citizen and a volunteer in the Royal Air Force, stated in his tribute to Younghusband, "nevertheless it was his presence that gave the congresses their distinct character, and that infused into the gatherings [...] the sense of unity and fellowship." ${ }^{82}$ He continued that "it was a real tragedy that just when the World Congress of Faiths was getting into its stride and beginning to make itself felt, war broke out and, and soon afterwards Sir Francis died. How much the Congress depended on him became evident as soon as he was gone." Landau ended his tribute by saying, "I found that I could no longer give wholehearted allegiance to the cause when its torch-bearer has passed from my sight." 83 Although there was a sense of loss, as well as shock among the WCF members and Younghusband's death had caused a major disruption, the WCF moved on and eventually became a "continuing memorial" for Younghusband. ${ }^{84}$

77 Seaver, Francis Younghusband, 344.

78 Seaver, Francis Younghusband, 344.

79 Seaver, Francis Younghusband, 344.

80 Seaver, Francis Younghusband, 344.

81 Seaver, Francis Younghusband, 344-345.

82 Seaver, Francis Younghusband, 345.

83 Seaver, Francis Younghusband, 346.

84 Braybrooke, Faiths in Fellowship, 14. 
Second, as a result of their financial struggles towards the end of WWII, the Executive Committee had a period where they recommended putting the organization into "cold storage." ${ }^{85}$ Other members were, however, vehemently opposed to this idea, resulting in some members donating funds to keep the organization running in the form of 150 pounds each. Baroness of Ravensdale also donated 150 pounds for the organization to re-open an office in London, portraying the relevance WCF had for members. ${ }^{86}$ Regardless, committee officers of the WCF spoke about how dire the financial situation of the WCF had become, to the point that they could not afford a part-time secretary.

This led to a number of changes that indicate the direction the WCF was moving towards. Baron Palmstierna, a Swedish minister living in the UK and a member of the WCF, expressed in his note of resignation from the WCF on 23 November 1949 that some WCF Executive Officers and members were shying away from a reality that the "time for big congresses as held in the past was over owing to financial and other difficulties." Palmstierna instead suggested that partnering with movements in other countries focused on interreligious engagement might be a good idea, such as the World Alliance for International Fellowship. ${ }^{87}$ As a result, Heather McConnell, a new member who joined in 1948 after attending a series of lectures hosted by the WCF, suggested forming a youth committee as a way to broaden the organization's appeal. The last time the WCF had had active youth involvement was during the second WCF from 23-27 July 1937, which had four youth speakers. Afterwards, they unsuccessfully tried to maintain a youth council of the WCF. Although the attempt by Heather McConnell was not successful, the WCF finally reached a turning point in the 1950's that led to membership growth again when Sir John Stewart Wallace took over leadership. Eventually, the organization moved towards focusing more on publishing a regular journal and organizing small scale events, rather than big congresses.

After Younghusband's death, the IRD movement continued to grow. Charismatic leaders such as Younghusband were seen as the catalysts needed to spark the change. While his death impacted the organization, it resulted in restructuring WCF according to the vision of the surviving members, ensuring the continuation of the WCF. Today the IRD movement in the UK and the WCF itself has become more diverse as IRD has become more mainstream.

85 World Congress of Faiths, Meeting Minutes (Oct 29 $9^{\text {th }}$, 1945), MS 222 A 826 1/1, WCF Archives, University of Southampton.

86 World Congress of Faiths, Meeting Minutes (Oct 29 $9^{\text {th }}$, 1945), MS 222 A 826 1/1, WCF Archives, University of Southampton.

87 World Congress of Faiths, Meeting Minutes (Nov 23 $3^{\text {rd }}$, 1949), MS 222 A $8261 / 1$, WCF Archives, University of Southampton. 


\section{Conclusion: Lessons for Interreligious Dialogue from the Inception of the World Congress of Faiths}

In summary, this article has tried to show how - on an individual level - Younghusband's experiences with trauma triggered the foundation of the WCF. However, on a social level, this experience was framed within the context of the Great Depression and World War II, which allowed Younghusband's idea to establish the WCF, making it relatable to many of his peers. The trauma, disaster and empathy that played a role in fostering the mystical experiences of Sir Francis Younghusband, led him to engaging interreligious dialogue on a large-scale at the 1893 Parliament of the World's Religions and finally to found the WCF.

The WCF experienced its own sense of disaster and resilience combined with a constant underlying concept of empathy-building essential to interreligious dialogue. While at certain points, speakers during congresses introduced ideas that directly contradicted the idea of empathizing with the other, such as putting forth the notion of conversion, others focused on concepts such as humanism and universalism. The dialogue that the 1936 Congress allowed is a critical reason for why the WCF survived the Great Depression and WWII. While empathy played an essential underlying role in the inspiration behind the founding of the WCF in connection to experiences of trauma and disaster, larger lessons for the IRD movement also emerged from the early formation of the WCF. In the end, the death of Younghusband brought into question whether the WCF would continue or end, and indirectly whether the IRD movement in the UK would continue. Ten years after the death of Younghusband and through organizational re-structuring, the WCF and IRD both continued to transform and grow in the UK. Thus, a striking lesson for the IRD movement emerged from the founding of the WCF is not to create an over-reliance on a visionary leader. The makeup of the membership of the WCF portrays intellectual elitism and classism, including a lack of diversity beyond the individual speakers representing particular beliefs. Today, however, the WCF membership has grown to be much more diverse.

With regards to the first lesson for the IRD movement, the over-reliance on a founding leader can have ripple effects impacting the organizational structure and mission after the death or resignation of that visionary leader. As mentioned earlier, the leadership of the WCF and members were not prepared for Sir Francis Younghusband's death. While they were able to transition in the weeks after his death, it was not until nine years later, in the 1950's when the organization suf- 
ficiently adapted with new leadership and a re-drafted constitution to enable the WCF to smoothen the operations of the organization. This opened up space in the WCF for seekers and led to congresses being arranged again after the end of the war. ${ }^{88}$ Dependency is a problem for most interfaith organizations including non-religious or interfaith-based organizations. The fact that the archives reflect that some WCF committee officers quit their positions after Younghusband's death portrays how debilitating the dependency on one leader had been.

It is interesting to relate this to the concept of having a "founder's syndrome", which is a new theory on organizational leadership touching upon a phenomenon impacting organizations historically. Founders syndrome defined can be the over-dependency on a founder who is charismatic and visionary, leading to stunting long-term sustainability and "social value creation." 89 This theory could in part explain the relationship that Sir Francis Younghusband had with the people of the Executive Committee where they did not essentially agree on the structure of the organization. This is reflected in Minutes where Younghusband's need for control becomes apparent. However, it does highlight the need for organizations to set not just a preparation plan for a replacement of a leader in the face of death, but also safeguards from becoming completely dependent on a founder.

With regard to the second lesson for IRD, it is important to highlight the role that Christianity played in the inception of the organization. While Younghusband's experiences with mysticism, as portrayed in the earlier part of his life, were essential to him becoming open to engaging people of different faiths, elements of Christian superiority still came in whether culturally, because of the fact he was a Lt- Col in the British Empire or because he needed the influence to attempt to coax the Anglican Church to be more comfortable with his explorations. The idea of Christian hegemony or agenda playing a role in the establishment of the early interreligious movement is not something that just impacted the WCF, as Hedges notes in relation to the 1893 World Parliament of Religions: "It should be noted, though, that an agenda of Christian supremacy and aspects of racial and cultural exclusion lay behind this event." 90 Moyaert goes on to say that "one could argue that this first World's Parliament of Religions was more of

88 World Congress of Faiths, Correspondence (1952 - 1956), MS 222 A 814 47, WCF Archives, University of Southampton.

89 Jessica Shortall, Emerging Topics Series \#7: Strategies for Managers Working within Founder's Syndrome organisations: http://www.socialenterprise.net/pdfs/Emerging_Paper_7_Jan_07.pdf (accessed: 24.5.2020).

90 Paul Hedges, Controversies in Interreligious Dialogue and Theology of Religions (London: SCM Press, 2010), 59. 
a Christian forum to which non-Christians were also invited than a true interreligious assembly" ${ }^{91}$, which portrays the triumphalism that wasn't just affecting the countries based on nationalism, but leaked into how Western Christianity became involved in organizing interreligious movements. Hedges uses Pui-lan Kwok to delve further into this argument:

In most interreligious dialogues conducted in Western ecumenical or academic settings, a handful of Third World elites, usually all males, are invited to speak as representatives of their traditions to a largely white Christian audience [...] The different 'world religions' are reified as if they were distinct and insoluble entities, represented primarily by male elite traditions, while interreligious differences are ignored and women's voices neglected. ${ }^{92}$

So, how did this affect the 1936 Congress and WCF? Unlike Rudolf Otto who insisted that the Christian lens should be used to engage mysticism, Younghusband was adamant that the WCF distance itself from using a solely Christian perspective in its mission and aims. This is connected to Rivera's theory explaining how the formation of the "ultimate openness" is where one "remains open to mystery and unpredictable possibilities: to the ineffable, unnameable, and unutterable." 93 In terms of Younghusband, his struggle with his spirituality and critical moments in his life were transformative in bringing him to interreligious dialogue and encouraging the other. As Rivera states, "in this ultimate we find a model for personal openness to the human other and the collective openness of socio-political systems." ${ }^{94}$ As a result, Younghusband's engagement with mysticism was a result of him not feeling comfortable with the type of Christianity he grew up within the UK.

However, that did not prevent the politics from forcing him to partially cater to the Anglican Church while still refusing to claim the Anglican perspective as the truth. What played a role in the formation of the WCF was privilege in connection to social stratification portrayed through who was invited to engage in the organization. Connections to classism and intellectual elitism also played a role in the larger organization with whom Younghusband deliberately sought to engage in dialogue.

By establishing a space for intellectual elites to engage in dialogue and encounter each other based on faith, the WCF effectively established a space excluding youth and others who were capable of engaging in dialogue, but perhaps not from a privileged or intellectual perspective. This is important to acknowl-

91 Moyaert, “Interreligious Dialogue," 195.

92 Hedges, Controversies in Interreligious Dialogue and Theology, 64.

93 Rivera, A Touch of Transcendence, 136.

94 Rivera, A Touch of Transcendence, 136. 
edge, because too often the darker side of the early history of the interreligious movement is hidden or brushed aside, preventing a completely transparent dialogue from occurring within the movement today.

The prominent leaders that played a role in the WCF can be seen both as negatively and positively affecting the organization. The involvement of the "movers and shakers" of the British Empire and of London, kept the organization from plummeting into cold storage or being put on hold as they used their own funds to keep it afloat until the 1950's where it resurfaced again. Today, Braybrooke mentioned that while the WCF has a large global membership base, they have stopped hosting international congresses. Instead, they have a journal that they publish that connects the international members to them, as reflected in their two narrower objectives today:

1 Publishing the "Interreligious Insight" journal on ideas, concepts and issues revolving around interfaith matters;

2 Organizing "conferences, meetings, retreats, visits and group travel". 95

Lastly, while the WCF objectives have narrowed, the membership and diversity of the WCF has grown allowing space for more voices to emerge in the Interreligious Insight Journal and in the small-scale conferences as the larger IRD movement becomes more mainstream in the UK.

\section{Bibliography}

\subsection{Primary Sources}

WCF Archives, University of Southampton:

Francis Younghusband, BBC Broadcast Script (June 21 1936), MS 222 A 826 3/98, WCF

Archives, University of Southampton, 1-2.

Francis Younghusband, Proposal for an International Congress of a World Fellowship of Faiths (June 1936), MS 222 A 826 2/2, WCF Archives, University of Southampton, 4.

Frank Smythe, News Clipping: Lt.-Col. Sir Francis Younghusband (1942), MS 222 A 826 1/1,

WCF Archives, University of Southampton.

George Harrison, Unpublished Manuscript: Younghusband Anthology of Divine Fellowship, 212 A814 56/2, WCF Archives, University of Southampton.

World Congress of Faiths, Annual Meeting Paper (June $4^{\text {th }}$, 1943), MS 222 A 826 2/1, WCF

Archives, University of Southampton.

95 World Congress of Faiths, About WCF: http://www.worldfaiths.org/what-we-do/ (accessed: 24.5.2020). 
World Congress of Faiths, Correspondence (1952-1956), MS 222 A 814 47, WCF Archives, University of Southampton.

World Congress of Faiths, Its Objects, Message and Work, MS 222 A $826 / 3 / 98$, WCF Archives, University of Southampton.

World Congress of Faiths, Its Objects, Message and Work, MS 222 A $826 / 3 / 98$, WCF Archives, University of Southampton, 3.

World Congress of Faiths, Meeting Minutes (1945), MS 222 A 826 2/1, WCF Archives, University of Southampton.

World Congress of Faiths, Meeting Minutes (Nov 23 $3^{\text {rd }}$, 1949), MS 222 A 826 1/1, WCF Archives, University of Southampton.

World Congress of Faiths, Meeting Minutes (Nov 27 $7^{\text {th }}$, 1945), MS 222 A 826 2/1, WCF Archives, University of Southampton, 1-3.


University of Southampton.

World Congress of Faiths, Meeting Minutes (Oct 29 ${ }^{\text {th }}$, 1945), MS 222 A 826 1/1, WCF Archives, University of Southampton.

World Congress of Faiths, Minutes detailing the development of leadership (from 1936-1949), MS 222 A 826 1/1, WCF Archives, University of Southampton.

World Congress of Faiths, Minutes of the Executive Committee Meeting (1936), MS 222 A 826 2/1, WCF Archives, University of Southampton.

World Congress of Faiths, Program and Agenda of the first World Congress of Faiths (July $3^{\text {rd }}$ $\left.18^{\text {th }}, 1936\right)$, MS 222 A $826 / 3 / 98$, WCF Archives, University of Southampton.

World Congress of Faiths, Program and Agenda of the first World Congress of Faiths (July $3^{\text {rd }}-$ $18^{\text {th }}$, 1936), MS 222 A $826 / 3 / 98$, WCF Archives, University of Southampton, 3.

The Younghusband Collection, British Library, London:

N.A., Talk at Westerham / Kent, MSS EUR F 197/119, The Younghusband Collection, British Library, London, 11.

World Congress of Faiths, Program and Agenda of the first World Congress of Faiths, MSS EUR F 197/119, The Younghusband Collection, British Library, London, 3.

\subsection{Secondary Sources}

Allen, Charles. "The Myth of Chumik Shenko," History Today 54 (2004), http://www.historyto day.com/charles-allen/myth-chumik-shenko (accessed: 24.5.2020).

Braybrooke, Marcus. "The Spiritual Basis of Interfaith Work.” Dialogue \& Alliance 19 (2005/06): 23-27.

Braybrooke, Marcus. Faiths in Fellowship: A Short History of the World Congress of Faiths and its Work. London, UK: The World Congress of Faiths, 1976.

Braybrooke, Marcus. Widening Vision: The World Congress of Faiths and the Growing Interfaith Movement. Oxford, UK: Braybrooke Press, 2013.

Brundage, Anthony. Going to the Sources: A Guide to Historical Research and Writing. Wheeling, Illinois: Harlan Davidson Inc, 2002.

Carrington, Michael. "Officers, Gentlemen and Thieves: The Looting of Monasteries during the 1903/4 Younghusband Mission to Tibet." Modern Asian Studies 37 (2003): 81-109. 
Fowler, James W. Stages of Faith: The Psychology of Human Development and the Quest for Meaning. New York: HarperCollins, 1995.

Fredericks, James L. "A Universal Religious Experience? Comparative Theology as an Alternative to a Theology of Religions." Horizons 22 (1995): 67-87.

French, Patrick. Younghusband: The Last Great Imperial Adventurer. London: HarperCollins, 1994.

Friday, John R. "Religious Experience, the Hermeneutics of Desire, and Interreligious Dialogue.” Theological Studies 74 (2013): 581-604.

Hedges, Paul. Controversies in Interreligious Dialogue and Theology of Religions. London: SCM Press, 2010.

Hull, A. M. A. "Colonel Younghusband's mission to Lhasa 1904: parliament, the British government and the 'forward policy' in Tibet,". MA Thesis: Durham University, 1989.

Moyaert, Marianne, "Interreligious Dialogue." In Understanding Interreligious Relations, edited by David Cheetham, Douglas Pratt and David Thomas, 193-271. Oxford: Oxford University Press, 2013.

Otto, Rudolf. The Idea of the Holy, trans. John W. Harvey. London: Oxford University Press, 1936.

Peacock, William Arthur. Fellowship through Religion. London: World Congress of Faiths, 1956.

Rivera, Mayra. A Touch of Transcendence: A Postcolonial Theory of God. Louisville, Kentucky: Westminster John Knox Pres, 2007.

Seaver, George. Francis Younghusband: Explorer and Mystic. London: John Murray, 1952.

Shortall, Jessica. "Emerging Topics Series \#7: Strategies for Managers Working within Founder's Syndrome organisations," Social Enterprise Associates, (2007): 1-16. http:// www.socialenterprise.net/pdfs/Emerging_Paper_7_Jan_07.pdf (accessed: 24.5. 2020).

University of Maryland, ed. Definition: Archives: http://lib.guides.umd.edu/c.php?g= 466216\&p=3189975 (accessed: 24.5.2020).

World Congress of Faiths. About World Congress of Faiths: http://www.worldfaiths.org/ (accessed: 24.5.2020).

Younghusband, Francis. Modern Mystics. London: Books for Libraries Press, 1935.

Younghusband, Francis. The Light of Experience. Boston and New York: Houghton Mifflin Company, 1927.

Younghusband, Francis. Vital Religion: A Brotherhood of Faith. New York: E.P. Dutton and Company Inc., 1940.

\section{Annex}

\section{Pamphlet of the World Congress of Faiths: Its Objects, Message and Work}

1. To have an international presence through hosting large international congresses with representatives of "world faiths" from foreign countries.

2. Establish an international council. 
3. Open branches of the WCF abroad to "bring our message to international attention".

4. Regular communication with members of international and local happenings relation to interreligious dialogue through the "chairman's quarterly letters" [similar to a newsletter].

5. Host regular receptions and networking events "to meet distinguished foreign visitors to England"

Three types of meetings:

- Regular membership only meetings held weekly or monthly.

- Public meetings hosted in major cities with universities and schools as a way to attract "the younger generations".

- Group meetings for the "common study of all living faiths of the world" based on experience and not solely on intellectual thoughts.

Goals of these events are defined in three ways:

- $\quad$ To provide a space where people can "learn what others believe, what they think about life today and how they pray, meditate and worship".

- Meetings are designed to attract teachers and health/social workers.

- The events and meetings additionally provide an opportunity "for members of local interfaith groups to meet people from different parts of the county and the world who share their concern". ${ }^{96}$

96 World Congress of Faiths, Its Objects, Message and Work, MS 222 A 826 /3/98, WCF archives, University of Southampton, 4-5. 
